\title{
INFLUENCE OF OCEANOGRAPHIC SEASONALITY AND DREDGING ACTIVITIES ON THE FISH LARVAE ASSEMBLAGE IN THE PORT OF ARATU, TODOS OS SANTOS BAY
}

\author{
MALTEZ, L. C. ${ }^{1 *}$; MAFALDA JUNIOR, P. O. ${ }^{1} \&$ NEUMANN-LEITÃO, S. ${ }^{2}$ \\ 1 - Laboratório de Plâncton, Departamento de Zoologia, Instituto de Biologia, Universidade Federal \\ da Bahia, Rua Ademar de Barros s/n, Ondina, Salvador - BA, Brasil. \\ 2 - Departamento de Oceanografia, Centro de Tecnologia, Universidade Federal de Pernambuco, Av \\ Arquitetura s/n, Cidade Universitária, Recife - PE, Brasil. \\ *Corresponding author: lucascmaltez@gmail.com
}

\begin{abstract}
Maltez, L. C.; Mafalda Junior, P. O. \& Neumann-Leitão, S. (2014) Influence of oceanographic seasonality and dredging activities on the fish larvae assemblage in the Port of Aratu, Todos Os Santos Bay. Braz. J. Aquat. Sci. Technol. 18(2): 1-10. eISSN 1983-9057. DOI: 10.14210/bjast.v18n2.p1-10 The aim of this study was to evaluate the impact of dredging activity to deepen the Port of Aratu on fish larvae assemblage structure. Samples were collected before, during and after dredging and at 6 sampling stations during both the flood and ebb tide (only during the dry season). Ichthyoplankton

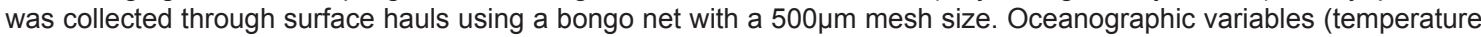
and salinity), water quality (dissolved oxygen and turbidity) and nutrients (ammonia and total phosphorus) were obtained simultaneously. During dredging, the lowest density of eggs and larvae, family richness and diversity were registered, with a subsequent recovery observed after dredging. Multivariate ordination showed the great differences between samplings, which demonstrated temporal variability in the distribution and abundance of ichthyoplankton in the port of Aratu (Bahia, Northeastern Brazil), in response to the seasonality of oceanographic characteristics of the water masses and changes in water quality, possibly associated with dredging activities.
\end{abstract}

Keywords: oceanographic variables, water quality, nutrients, ichthyoplankton, Brazil.

\section{INTRODUCTION}

Global accessibility to ports and waterways is vital to the economic growth of coastal regions (Engler et al., 1991). To meet this need, it is necessary for some ports to increase the depth of their access channels, docking and evolution basins to allow larger boats to the port areas. For this reason, dredging activities are conducted worldwide and involve the excavation of sediment, transport and subsequent disposal of dredged material at a given location (Patchineelam et al., 2008).

Dredging is a necessity that if well managed, can result in positive aspects for development in coastal areas (Patchineelam et al., 2008). However, despite its economic importance, dredging introduces potential impacts to the environment and is currently one of the main problems in coastal management (Borja et al., 2010).

The most frequent dredging impacts on aquatic ecosystems include the capture of organisms by the dredge, modification in the benthic community and physical changes of the circulation patterns and currents. In addition, there is an increase in the concentration of suspended solids and turbidity, a reduction in light penetration, nutrient upwelling and organic matter and toxic substances present in the sediment that cause intense water quality changes (Armengol,
1998; Newell et al., 1998; Lewis et al., 2001; Wilber \& Clarke, 2001).

The impacts of dredging activity are worse in port areas because the marine environment of bays and estuaries, where the ports are located, usually function as receptors for contaminants from industrialization and urbanization of the adjacent coastal zone (Cundy et al., 2003; Taylor et al., 2004). Thus, disturbing sediments in these areas often results in high levels of contamination, especially from heavy metals and hydrocarbons (Yeager et al., 2010). In addition, high concentrations of nutrients and organic matter (Kennish, 1986) become available in the water column during dredging.

Studies involving planktonic communities and evaluating the effects of dredging in aquatic ecosystems have been conducted (Nayar et al., 2004; Veado \& Resgalla, 2005; Wang et al., 2005; Li et al., 2007; Wu et al., 2008; Zhang et al., 2010). In these studies, the planktonic organisms response changes that occur in the environment (Margalef, 1983) and can be utilized as an efficient tool for assessing the impacts of this activity. In northeastern Brazil, some studies evaluated the effects of dredging and the construction of ports on the survival and growth of organisms, including phytoplankton, zooplankton and Ichthyoplankton (Neumann et al., 1998; Koening et al., 2002; Silva et al., 2004). Recently, Ferreira et al. (2012) evaluated the impact 
of dredging the port of Aratu, Todos os Santos Bay (Bahia) on the phytoplankton community.

The effects of dredging on fish eggs and larvae have been evaluated in several laboratory experiments and are mainly related to increased concentrations of suspended sediment and turbidity and changes in water quality (Auld \& Schubel, 1978; Morgan et al., 1983; Boehlert \& Morgan, 1985; Wilber \& Clarke, 2001; Colby \& Hoss, 2004; Lutz et al., 2012). However, studies that address the effect of dredging on the structure of fish larvae assemblages are few (Jiang et al., 2008; Bezerra Jr. et al., 2011) and none have been conducted at Todos os Santos Bay.

The objective of this study was to monitor the ichthyoplankton assemblage adjacent to the port of Aratu, Todos os Santos Bay (TSB), Bahia, Brazil, before, during and after the dredging activity. The correlation between the fish larvae assemblage structure and oceanographic variables, water quality and nutrients was examined in an attempt to understand the possible effects caused by the dredging process.

\section{MATERIAL AND METHODS}

\section{Study area}

Todos os Santos Bay is the second largest coastal indentation of the Brazilian coastline, with an area of $1.086 \mathrm{~km}^{2}$. TSB is highly populated along its northern shore, where over 3 million people are devoted to fishing, agriculture and industrial activities (Lessa et al., 2001). The salinity and temperature variations in the main section of TSB are due to the open marine influence ( 36.7 to 33.0 and $24^{\circ} \mathrm{C}$ to $30^{\circ} \mathrm{C}$, respectively (Wolgemuth et al., 1981).

This region is influenced by a tropical climate with well-defined dry (August to February) and wet (March to July) seasons, when it rains approximately $60 \%$ of the total annual precipitation (Pereira \& Lessa, 2009).

Aratu Bay is a small system that includes the bay itself and a $4 \mathrm{~km}$ long channel (Canal de Cotegipe) that connects the central part of the bay to the Port of Aratu in TBS (Fig. 1). Aratu Bay is shallow, with an average depth of $1.8 \mathrm{~m}$ and a maximum width and length of 214 $\mathrm{m}$ and $4.1 \mathrm{~km}$, respectively (Pereira \& Lessa, 2009). The fluvial discharge from a small catchment area reaches the bay via two perennial rivers, Santa Maria and Cotegipe Rivers, which together have an estimated average annual discharge of $1.65 \mathrm{~m}^{3} \mathrm{~s}^{-1}$ (CRA, 2000).

The wind field shows strong seasonality, blowing from $E$ and $S E$ in the dry season and $S$ and $S W$ in the wet season. The circulation inside TSB is mostly tidally driven and does not vary significantly throughout the year (Cirano \& Lessa, 2007). The tides are semidiurnal with currents in the bay, mainly bi-directional and stronger during the ebb tide in most of the bay (Lessa et al., 2001).

In spite of the ecological and economic importance of the Aratu harbor, in the western section of Todos os Santos Bay, there is no published work ad-
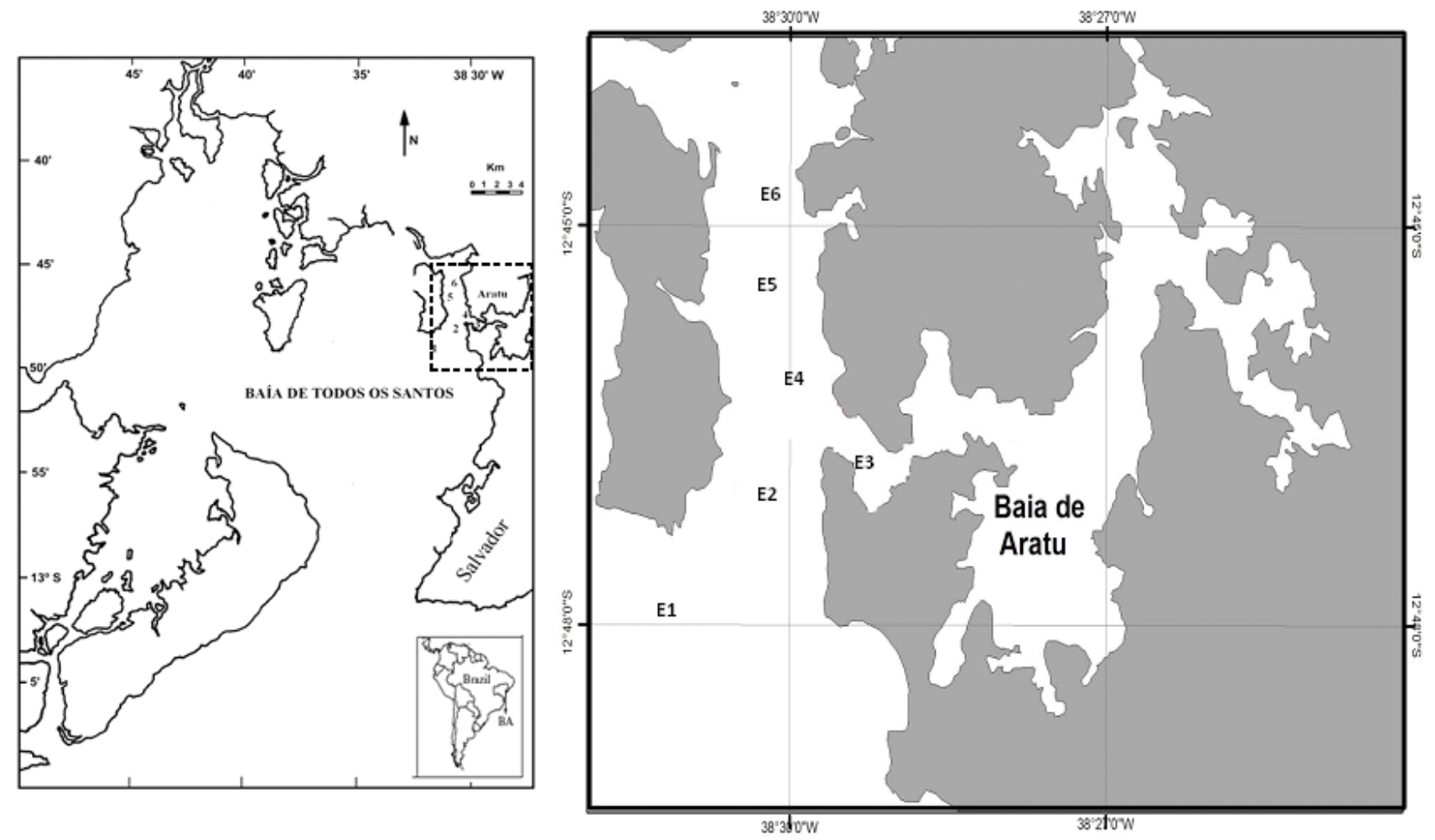

Figure 1 - The location of sampling stations in the region adjacent to the Aratu Bay (Port of Aratu), Todos os Santos Bay, Bahia. 
dressing communities of fish larvae; the only research on fish larvae assemblage structure addresses the influence of petroleum activities in the northern Todos os Santos Bay (Katsuragawa et al., 2011; Mafalda Jr. et al., 2008) near Aratu Bay.

Larval fishes are quite fragile and especially susceptible to environmental and water quality variations such that any environmental impact may be catastrophic to these populations (Katsuragawa et al., 2011).

\section{Sampling}

The subsurface collections were made with a small speedboat at 6 sampling stations distributed along the Aratu harbor at Todos os Santos Bay (Bahia, Brazil) (Figure 1). Collections were made both in flood and ebb tides in February 2010 (before dredging), September 2010 (during dredging) and November 2011 (after dredging) and only during the dry season. The collections were made in flood and ebb tides, within 4 hour intervals, and were performed only with the objective of increasing the significance of the sampling. The stations depths presented a high amplitude that varied between 5 and $20 \mathrm{~m}$. Salinity and temperature were measured at each station using a refractometer and a thermometer, respectively. Water quality data (dissolved oxygen and turbidity) and nutrients (ammonia and total phosphorus) were collected at the subsurface $(10 \mathrm{~cm})$ with a Van Dorn bottle and analyzed in the laboratory according to SMEWW (2005).

Ichthyoplankton was collected with a conical plankton net (500 $\mu \mathrm{m}$ mesh size) with a Hydrobios flowmeter attached to the net mouth. The hauls were horizontal at the subsurface and 5 minutes long, and the boat maintained an average speed of $2 \mathrm{kt}\left(1 \mathrm{~m} \cdot \mathrm{s}^{-1}\right)$. The samples were then placed in $500 \mathrm{ml}$ polyethylene bottles and preserved in $4 \%$ neutralized formalin. The calculation of the volume of water filtered by the plankton net was conducted using the following formula: $V=a . n . c$, where: $V=$ volume of filtered water $\left(m^{3}\right)$; a=mouth area of the net $\left(m^{2}\right) ; n=$ number of rotations during the hauls (rot); $c=$ calibration factor of the flowmeter $\left(\mathrm{m}^{- \text {rot }^{-1}}\right)$.

Identification of the larvae and young fish were determined at the minor possible taxonomic unit using the following literature, among others: Fahay (1983), Leis \& Remmis (1983) and Richards (2006). The scientific nomenclature followed Nelson (1994).

\section{Statistical analysis}

The density (organisms. $100 \mathrm{~m}^{-3}$ ) was obtained from the quotient between the total number of eggs or larvae of fish obtained in each sample $(\mathrm{N})$ and the volume of filtered water $(\mathrm{V})$, using the following for- mula: $\mathrm{N} / 100 \mathrm{~m}^{3}=(\mathrm{N} / \mathrm{V}){ }^{*} 100$. The relative abundance (\%) was calculated according to the following formula: $\mathrm{Ar}=\left(\mathrm{Na}^{*}{ }^{100}\right) / \mathrm{NA}$, where $\mathrm{Na}$ is the total number of fish larvae of each family obtained in the sample and NA is the total number of fish larvae in the sample. The indices of richness (Margalef), evenness (Pielou) and diversity (Shannon-Wiener) were estimated. The criteria adopted for determining the dominant families was a relative abundance greater than 100/S, where $S$ is the number of taxa identified in the study.

The analysis of the temporal variability of the ichthyoplankton community and water quality was performed with a non-parametric Friedman ANOVA using Bioestat 5.0 software. Detrended Canonical Correspondence Analysis (DCCA) was used to investigate the environmental gradient. Because a linear gradient was found, we opted for Redundancy Analysis (RDA) to check through the ordination diagram of the main pattern of variation in the ichthyoplankton as related to the function of the oceanographic variables (Ter Braak, 1986). The DCCA and RDA were calculated by the Canoco for Windows v. 4.5 (Ter Braak \& Smilauer, 1998). The RDA analysis was performed only with oceanographic variables that showed a statistically significant difference between samples (Friedman, $p<0.05$ ).

\section{RESULTS}

\section{Oceanographic variables, water quality and nutrients}

Despite all the sampling campaigns were carried out during the considered dry period (Pereira \& Lessa, 2009), the rain cycle differed from the expected during the study and the campaigns of dredging and post-dredging were performed in periods with high rainfall (INMET, 2012).

The temporal variability of oceanographic variables (salinity and temperature), water quality (dissolved oxygen and turbidity) and nutrients (ammonia and total phosphorus) were studied.

The temperature showed higher values before the dredging, when it ranged between 29.1 and $33.9^{\circ} \mathrm{C}$ (average of $30.5^{\circ} \mathrm{C}$ ). During dredging, the temperatures were the lowest and ranged between 23.8 and $27.5^{\circ} \mathrm{C}$ (average of $26.2^{\circ} \mathrm{C}$ ). After dredging, the temperature ranged from 27.1 to $30.8^{\circ} \mathrm{C}$ (average of $29.2^{\circ} \mathrm{C}$ ).

The salinity was higher before the dredging, oscillating between 35.5 and 38.5 (average of 36.9 ). During dredging, salinity fluctuated between 30 and 35.5 (average of 34.4). After dredging, the smallest amplitude was observed, with values between 34 and 35 (average of 34.8). 
TABLE 1 - Averages of variables from each sampling and the results of Friedman's ANOVA ( $p$ ) and Multiple Comparisons test of Dunn ( $p$ ) were utilized to study the temporal variability of water quality during the study in the region adjacent to the port of Aratu, Todos os Santos Bay, Bahia (1, PRE: Pre-dredging; 2, DREDGE: Dredging; 3, POST: Post-dredging).

\begin{tabular}{|c|c|c|c|c|c|c|c|}
\hline & PRE & DREDGE & POST & ANOVA & $1 \times 2$ & $1 \times 3$ & $2 \times 3$ \\
\hline Temperature $\left({ }^{\circ} \mathrm{C}\right)$ & 30.5 & 26.2 & 29.2 & $<0.0001$ & $<0.05$ & & $<0.05$ \\
\hline Salinity & 36.9 & 34.4 & 34.8 & 0.0001 & $<0.05$ & $<0.05$ & \\
\hline Oxygen $\left(\mathrm{mg} \cdot \mathrm{L}^{-1}\right)$ & 7.3 & 5 & 2.8 & $<0.0001$ & $<0.05$ & $<0.05$ & $<0.05$ \\
\hline Turbidity (NTU) & 6,2 & 5,5 & 3,1 & 0.1353 & & & \\
\hline Ammonia $\left(\mathrm{mg} \cdot \mathrm{L}^{-1}\right)$ & 0.2 & 0.233 & 0.075 & 0.0131 & & $<0.05$ & \\
\hline Total phosphorus (mg. $\left.\mathrm{L}^{-1}\right)$ & 0.016 & 0.045 & 0.039 & 0.0018 & $<0.05$ & $<0.05$ & \\
\hline
\end{tabular}

The water had more oxygen prior to dredging, when the dissolved oxygen values were between 5.6 and $8.8 \mathrm{mg} \cdot \mathrm{L}^{-1}$ (average of $\left.7.3 \mathrm{mg} \cdot \mathrm{L}^{-1}\right)$. During - and after - dredging values were lower, varying between 4.4 and $6 \mathrm{mg} . \mathrm{L}^{-1}$ (average of $5 \mathrm{mg} \cdot \mathrm{L}^{-1}$ ) (dredging), and between 2.3 and 3.2mg.L-1 (average 2.8mg. $\mathrm{L}^{-1}$ ) (after dredging).

The turbidity presented a higher amplitude before dredging, varying between 2 and 11 NTU (average of 6.2 NTU). During dredging, the turbidity ranged between 1.8 and 9.4 NTU (average of 5.5 NTU), and after dredging, the lowest turbidity values were obtained, varying between 1 and 4.3 NTU (average of 3 NTU).

Before the dredging, the concentration of ammonia did not vary spatially (i.e., it was the same $\left(0.2 \mathrm{mg}^{\mathrm{L}} \mathrm{L}^{-1}\right)$ at all of the sampling stations). During dredging, the values were the highest, oscillating between 0.03 and $0.61 \mathrm{mg} \cdot \mathrm{L}^{-1}$ (average of $0.23 \mathrm{mg} \cdot \mathrm{L}^{-1}$ ). After dredging, the values were lower and occurred between 0.03 and $0.1 \mathrm{mg}^{-L^{-1}}$ (average of $0.075 \mathrm{mg}^{-L^{-1}}$ ).

The concentration of total phosphorus presented lower values before dredging (between 0.002 and $0.026 \mathrm{mg}^{\mathrm{L}-1}$ ), with an average value of $0.016 \mathrm{mg} \cdot \mathrm{L}^{-1}$. During dredging, the concentration increased, showing values between 0.004 and $0.064 \mathrm{mg} \cdot \mathrm{L}^{-1}$ (average of $0.045 \mathrm{mg} . \mathrm{L}-1$ ), almost 3 times higher than that before dredging. After dredging, there was a small reduction, and the concentrations were between 0.03 and $0.049 \mathrm{mg} . \mathrm{L}^{-1}$ (average of $0.039 \mathrm{mg} \cdot \mathrm{L}^{-1}$ ).

All of the variables analyzed showed a statistically significant difference (Friedman, $p<0.05$ ) between samples, with the exception of turbidity $(p=0.1353)$ (Table 1). The variability of the oceanographic variables (temperature and salinity) were more influenced by seasonality than dredging. Conversely, the variability of water quality (oxygen and turbidity) and nutrients (ammonia and total phosphorus) were more influenced by dredging.

\section{Ichthyoplankton assemblage}

A total of 261 larvae were captured throughout the study and belonged to seven Orders (Clupeiformes, Syngnathiformes, Beloniformes, Atheriniformes, Perciformes, Pleuronectiformes and Tetraodontiformes) and 17 families. Table 2 shows the total abundance, relative abundance and the number of larvae identified in each sampling.

Based on the "100/taxa number" criteria, 5 families were considered dominant in the study area and showed relative abundance more than $5.9 \%$ during the study (Blenniidae, Carangidae, Engraulidae, Gerreidae and Labrisomidae) (Table 1). Together, these 5 families represented approximately $81.7 \%$ of the total abundance.

During sampling previous to dredging, 125 larvae, representing $48 \%$ of the total abundance, were captured, while during dredging, only 23 larvae (9\%) were found, representing a great reduction in capture. During post-dredging sampling, abundance increased again, and 113 (43\%) larvae were captured. In addition to a lower abundance of larvae, dredging also presented a smaller number of taxa. Among the 17 families identified, 13 were present previous to dredg-

TABLE 2 - Abundance by campaign for pre-dredging (PRE), dredging (DREDGE), post dredging (POST), total abundance (TA) and relative abundance percentage (RA\%) for each family of fish larvae produced during the study in the region adjacent to the port of Aratu, Todos os Santos Bay, Bahia.

\begin{tabular}{lccccc}
\hline \hline & PRE & DREDGE & POST & TA & RA\% \\
\hline $\begin{array}{l}\text { CLUPEIFORMES } \\
\quad \text { Engraulidae }\end{array}$ & 21 & 11 & 10 & 42 & 16 \\
$\begin{array}{l}\text { ATHERINIFORMES } \\
\quad \text { Atherinopsidae }\end{array}$ & 1 & 0 & 6 & 7 & 2.7 \\
$\quad$ BELONIFORMES & & & & & \\
$\quad$ EXocoetidae & 2 & 0 & 1 & 3 & 1.1 \\
$\quad$ Hemiramphidae & 0 & 0 & 3 & 3 & 1.1 \\
GASTEROSTEIFORMES & & & & & \\
$\quad$ Syngnathidae & 3 & 0 & 0 & 3 & 1.1 \\
PERCIFORMES & & & & & \\
$\quad$ Serranidae & 0 & 0 & 1 & 1 & 0.4 \\
$\quad$ Carangidae & 38 & 2 & 10 & 50 & 19 \\
$\quad$ Gerreidae & 16 & 0 & 3 & 19 & 7.2 \\
$\quad$ Haemulidae & 8 & 1 & 2 & 11 & 4.2 \\
$\quad$ Sparidae & 4 & 2 & 1 & 6 & 2.3 \\
$\quad$ Pomacentridae & 1 & 0 & 0 & 1 & 0.4 \\
$\quad$ Labrisomidae & 7 & 1 & 27 & 35 & 13.3 \\
$\quad$ Blenniidae & 18 & 4 & 47 & 69 & 26.2 \\
$\quad$ Gobiidae & 2 & 0 & 0 & 2 & 0.8 \\
$\quad$ Microdesmidae & 0 & 1 & 0 & 1 & 0.4 \\
PLEURONECTIFORMES & & & & & \\
$\quad$ Achiriidae & 4 & 1 & 1 & 6 & 2.3 \\
$\quad$ TETRAODONTIFORMES & & & & & \\
$\quad$ Tetraodontidae & 0 & 0 & 1 & 1 & 0.4 \\
$\quad$ Total larvae & 125 & 23 & 113 & & \\
Number of families & 13 & 8 & 13 & & \\
\hline \hline & & & & & \\
\hline
\end{tabular}


ing, 8 during dredging and 13 during post-dredging. That is, pre-dredging and post-dredging presented greater fish larvae richness, with $76.7 \%$ of the identified larvae, while during dredging only $47.2 \%$ of the taxa were present.

The average number of families per sampling station was 4.9 during pre-dredging, 0.9 during dredging and 3.1 during post-dredging, varying significantly (Friedman, $p<0.05$ ) among the three campaigns.

Margalef richness, Shannon-Wiener diversity and Pielou evenness also varied significantly (Friedman, $\mathrm{p}<0.05$ ) and showed lower values during dredging. The average value of the Margalef richness index was 3.9 during pre-dredging, 0.7 during dredging and 2.1 during post-dredging. The average value of the Shannon-Wiener index was 0.6 during pre-dredging, 0.1 during dredging and 0.3 during post-dredging. The Pielou evenness presented average values of 0.8 , 0.1 and 0.5 during pre-dredging, dredging and postdredging, respectively (Figure 2).

A significant reduction (Friedman, $p<0.05$ ) in the density of eggs and larvae was also observed during dredging. The average density of eggs (Figure 3 ) was 133.2 eggs. $100 \mathrm{~m}^{-3}$ during pre-dredging, was reduced to 18.92 eggs. $100 \mathrm{~m}^{-3}$ during dredging and was highest in post-dredging, with an average of 504.4 eggs. 100 $\mathrm{m}^{-3}$. The average density of larvae (Figure 4) presented similar values between pre- (14.4 larvae. $\left.100 \mathrm{~m}^{-3}\right)$ and post-dredging (14.9 larvae. $\left.100 \mathrm{~m}^{-3}\right)$, while during dredging, this value was 3.9 larvae. $100 \mathrm{~m}^{-3}$.

In regard to the average density of total larvae,the average density of the dominant families (Figure 5) was also lower during dredging, with the exception of the family Engraulidae, which presented its highest average density during this campaign (2.2 larvae. $100 \mathrm{~m}^{-3}$ ). Carangidae and Gerreidae showed greater density during dredging, with 2.8 and 1 larvae. $100 \mathrm{~m}^{-3}$, respectively, while the families Blennidae $\left(7.1\right.$ larvae. $\left.100 \mathrm{~m}^{-3}\right)$ and Labrisomidae (2.4 larvae. $100 \mathrm{~m}^{-3}$ ) presented a higher density during post-dredging. Pre-dredging was the only campaign in which the density of the "other families" (7.5 larvae. $\left.100 \mathrm{~m}^{-3}\right)$ overcame the characteristic families (6.9 larvae. $100 \mathrm{~m}^{-3}$ ) (Figure 6). Only the Blennidae (Friedman, $\mathrm{p}=0.0109$ ) and Carangidae families (Friedman, $p=0.0221$ ) showed significant differences between the campaigns for the average density of larvae.

\section{Multivariate analysis}

Detrended Canonical Correspondence Analysis (DCCA) was used to investigate the environmental gradient size. Because this was a linear gradient (1.430), we opted for Redundancy Analysis (RDA) to examine the ordination diagram and the primary pattern of variation in the community composition of

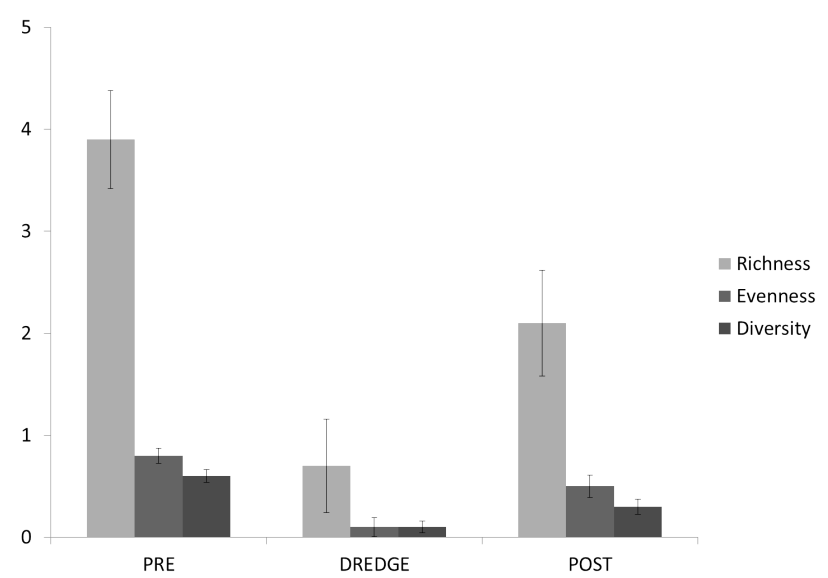

Figure 2 - The average ( \pm S.D.) values of richness (Margalef), evenness (Pielou) and diversity (Shannon-Wiener) obtained during pre-dredging (PRE), dredging (DREDGE) and post-dredging (POST) from the port of Aratu, Todos os Santos Bay, Bahia.

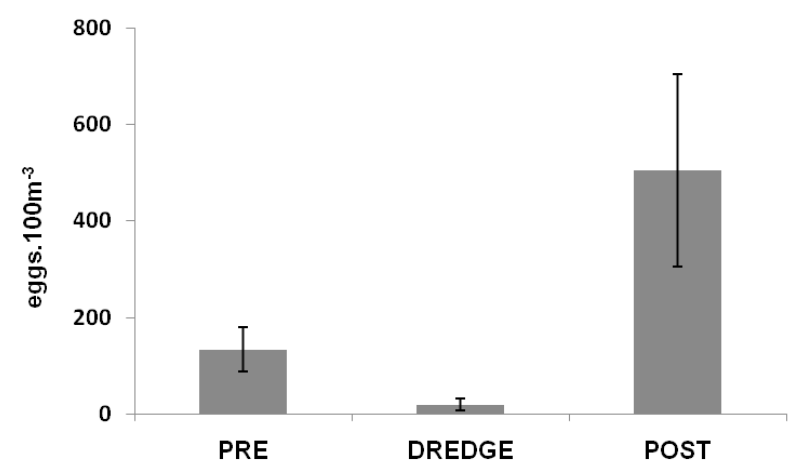

Figure 3 - The average ( \pm S.D.) density of fish eggs during predredging (PRE), dredging (DREDGE) and post-dredging (POST) from the port of Aratu, Todos os Santos Bay, Bahia.

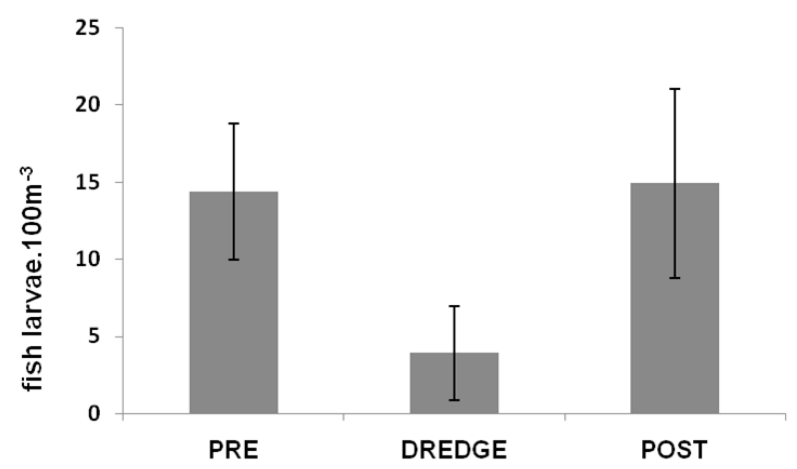

Figure 4 - Total average ( \pm S.D.) density of fish larvae during predredging (PRE), dredging (DREDGE) and post-dredging (POST) from the port of Aratu, Todos os Santos Bay, Bahia.

fish larvae on the basis of oceanographic variables. This analysis was considered statistically significant because the Monte-Carlo test presented $p=0.016$ for the first axis and $p=0.044$ for the sum of all of the canonical axes. The multiple regression coefficients between the oceanographic variables $(<0.7)$ obtained during the Redundancy Analysis indicate the absence of covariates (i.e., highly correlated variables). The ordination diagram (Figure 6) was constructed with the first 


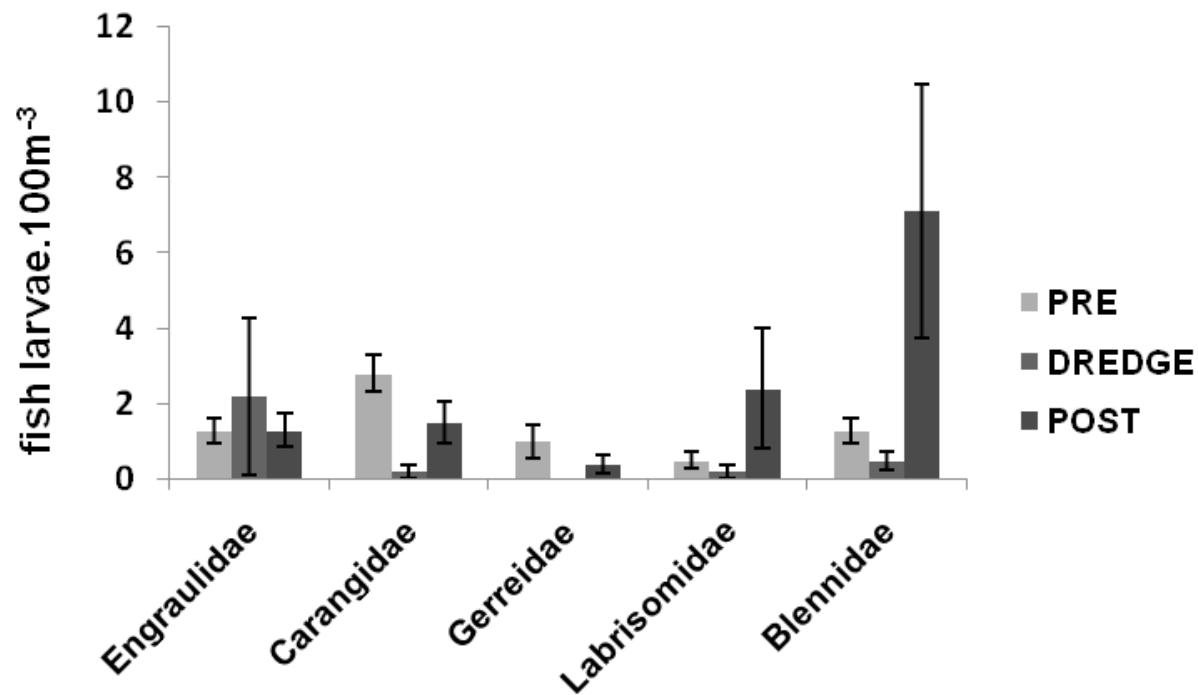

Figure 5- The average density of characteristic fish larvae during pre-dredging (PRE), dredging (DREDGE) and post-dredging (POST) from the port of Aratu, Todos os Santos Bay, Bahia.

two canonical axes of analysis of redundancy because they explained $92.1 \%$ of the accumulated percentage variation of the relationship between the Ichthyoplankton and water quality (Table 3 ). The sum of the eigenvalues was 23.4 when the ideal is greater than $20 \%$ (Table 3 ). This result shows that approximately $23 \%$ of the variability in Ichthyoplankton composition was explained by the oceanographic environmental gradient.

In this ordination diagram (Figure 6), there was a very clear separation between sampling stations depending on the structure of the body of water (temperature and salinity) and its quality (oxygen, ammonia and total phosphorus) as well as the ichthyoplankton composition. The pre-dredging sampling stations showed higher temperature, salinity and oxygen values and were associated with the highest densities of Carangidae, Gerreidae and Engraulidae. Dredging sampling stations were related with higher ammonia and total phosphorus concentrations and low density and richness of larvae. Finally, post-dredging sampling stations were associated with high larval densities of the Blennidae and Labrisomidae families.

\section{DISCUSSION}

\section{Oceanographic variables, water quality and nutrients}

The salinity values indicate the presence of two distinct water masses during the study. During predredging, the presence of a tropical water mass was found and was a result of the narrow (approximately $10 \mathrm{~km}$ long) continental shelf (Brandini et al., 1997) that advances towards the interior of the Todos os Santos Bay and reached the study area. This tropical water is part of the southward Brazil Current, which is characterized by salinity above 36 (Campos et al., 1995). With a salinity of approximately 35 , this coastal water was influenced by high rainfall and a consequent increase in the estuarine plume (Mafalda et al., 2004), which was present during dredging and post-dredging sampling.

A pattern of thermal seasonality in the study area was observed, which was characterized by higher temperatures in February (pre-dredging) and lower temperatures in September (dredging) and November (post-dredging). This pattern was also observed in the North area of Todos os Santos Bay (Mafalda Jr. et al., 2003) and in the Bahia north littoral (Mafalda Jr. et al., 2004). The higher temperature values (approximately $30^{\circ} \mathrm{C}$ ) in Todos os Santos Bay occur in

TABLE 3 -A summary of the redundancy analysis performed for the region adjacent to the port of Aratu, Todos os Santos Bay, Bahia.

\begin{tabular}{|c|c|c|c|c|c|}
\hline & & \multicolumn{4}{|c|}{ Axes } \\
\hline & & 1 & 2 & 3 & 4 \\
\hline Eigenvalues & & 0.187 & 0.028 & 0.014 & 0.005 \\
\hline Species-environment correlations & & 0.695 & 0.505 & 0.259 & 0.153 \\
\hline $\begin{array}{l}\text { Cumulative percentage variance } \\
\text { of species data }\end{array}$ & & 18.7 & 21.5 & 22.9 & 23.3 \\
\hline of species-environment relationship & & 80.0 & 92.1 & 97.9 & 99.9 \\
\hline $\begin{array}{l}\text { Sum of all Eigenvalues } \\
\text { Sum of Canonical eigenvalue }\end{array}$ & $\begin{array}{l}1.000 \\
0.223\end{array}$ & & & & \\
\hline
\end{tabular}




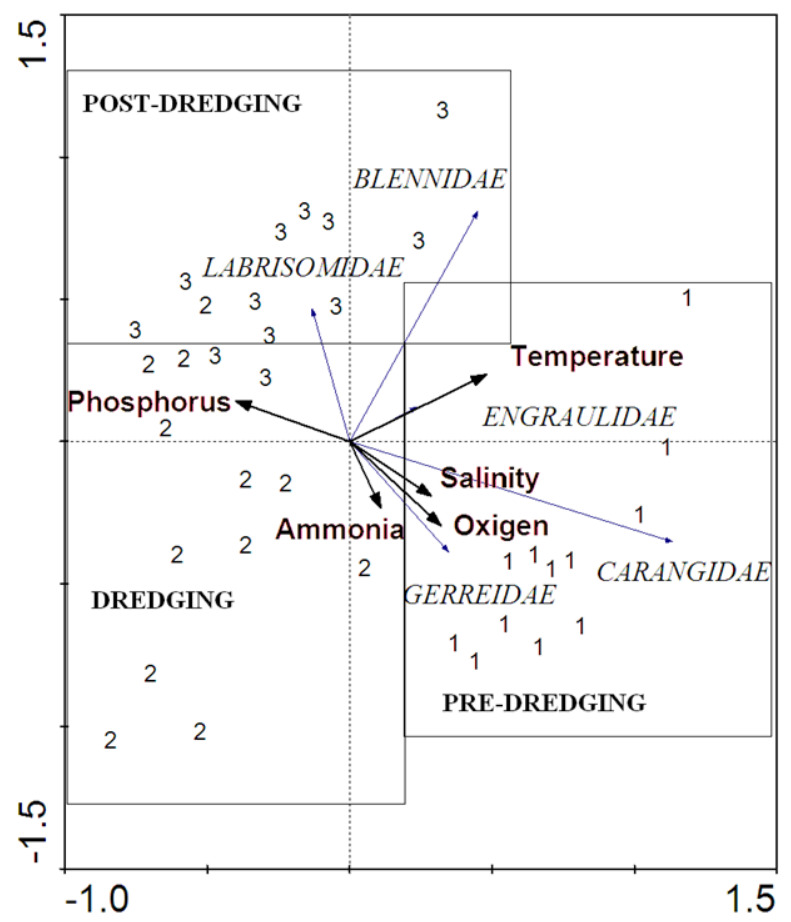

Figure 6 - An ordination diagram for redundancy analysis as related to the fish larvae assemblage with the oceanographic structure, water quality and nutrients in the port of Aratu, Todos os Santos Bay, Bahia (1, pre-dredging stations; 2, stations during dredging; 3, postdredging stations).

January, February and March (Cirano \& Lessa, 2007; Lessa et al., 2009).

The concentration of dissolved oxygen recorded were occasionally lower than $6 \mathrm{mg} \cdot \mathrm{L}^{-1}$, the minimum value recommended by the National Environmental Council for marine water and by CONAMA resolution 357 (CONAMA, 2005). The dissolved oxygen showed higher values during the pre-dredging (a reflection of the presence of tropical water) and lower values during dredging and post-dredging (due to the presence of coastal water). In addition, it is possible that dredging activity mobilized sediment and the upwelling of organic matter and nutrients that caused a reduction in the oxygen levels in the water column.

Turbidity values were low throughout the study, and it was the only parameter that did not vary significantly between samples. In addition, the turbidity increase during dredging was verified by Beretta (2012) from the results of sediment and water quality monitoring developed together with this study; the turbidity ranged from 1.8 to $37.6 \mathrm{mg} \cdot \mathrm{L}^{-1}$.

\section{Ichthyoplankton assemblage}

Significant differences were found between the periods for all structural indexes of the community with a large reduction in the density of eggs and larvae observed during dredging. In relation to pre-dredging, lower richness, diversity and evenness of taxa were observed, followed by a subsequent recovery, with growth in all of these structural indexes during post-dredging.
Bezerra Jr. et al. (2011), in a study on the port area of Suape in Pernambuco, observed low densities of larvae in an area subjected to different rates of dredging activities. Silva et al. (2004) also observed a low abundance of zooplankton in this same area, which was attributed to the resuspension of sediment (and increased turbidity) by dredging activities (Neumann et al., 1998) that affect primary productivity by reducing light penetration (Koening et al., 2002). When studying fish communities, Otero et al. (2006) and Queiroz et al. (2007) also found decreased richness and increased dominance of a few species caused by the dredging process.

Redundancy analysis showed a clear separation between the three campaigns, highlighting the importance of the water characteristics and quality in the variability of Ichthyoplankton.

The Ichthyoplankton in coastal waters is closely related to the system of currents and water masses present in the region, highlighting the importance of hydrological characteristics on its distribution (Vélez et al., 2005; Mafalda et al., 2006). Furthermore, salinity and temperature has been shown as important variables that control the distribution and abundance of planktonic organisms (Mouny \& Dauvin, 2002; Tackx et al., 2004; Strydom et al., 2003).

Man-made disturbances, such as dredging, can lead to environmental and water quality changes, resulting in negative effects for people (Kingsford \& Gray, 1996; Katsuragawa et. al., 2011) and affect- 
ing the distribution, abundance and composition of Ichthyoplankton, leading to changes in community structure (Whitfield \& Paterson, 2003).

The decrease in richness and the density of eggs and larvae of fish observed during the phase of dredging occurred simultaneously with increased density of phytoplanktonic organisms that were stimulated by the increased concentration of phosphorus and ammonia, as noted by Ferreira et al. (2012). These results highlight the negative influence of dredging activity on the temporal variability of Ichthyoplankton density and richness, which is possibly related to eutrophication, with low levels of oxygen and $\mathrm{pH}$ and higher turbidity due to the suspension of nutrients. By studying the impact of dredging to deepen the Itajaí-Açu River in the area of the port of Itajaí, Abreu et al. (2008) observed an increase in the availability of nutrients, leading to changes in water quality and the structure of the zooplanktonic community.

According to Margalef (1983), planktonic organisms respond quickly to environmental changes, as reflected in the composition and structure of these communities (Nogueira \& Matsumura-Tundisi, 1996). Thus, in the same way that these communities are quickly affected during dredging, they recover in a short time after dredging because the effects of dredging in the pelagic environment, although intensive, are generally short-lived.

The results of this study demonstrate a temporal variability in the composition and abundance of the fish larvae assemblage in the port of Aratu in response to oceanographic seasonality and changes of water quality and nutrients possibly stimulated by dredging activity.

\section{REFERENCES}

Abreu, J.G.N.; Rörig, L.R.; Resgalla Jr., C.; Almeida, T.C.M.; Pereira Fillho, J.; Bellotto, V.R.; Menezes, J.T. \& Schettini, C.A.F. 2008. Monitoramento ambiental na área de influência do Porto de Itajaí (SC). In: Boldrini, E.B. \& Paula, E.V. (org.) Gestão ambiental portuária: subsídios para o licenciamento das dragagens. Associação de Defesa do Meio Ambiente e Desenvolvimento de Antonina; Faculdades Integradas Espírita; Secretaria de Ciência e Tecnologia para inclusão social (MCT), Antonina. 179-190pp.

Armengol, J. 1998. Efectos ecológicos del dragado y vaciado del embalse de Barasona. Limnetica 14: 17-33.

Auld, A. H. \& Schubel J. H. 1978. Effects of suspended sediment on fish eggs and larvae: a laboratory assessment. Estuar. Coast. mar. Sci. 6: 153-164.
Beretta, M. 2012. Monitoramento da qualidade da água e do sedimento. Convênio SEP-CODEBA-UFBA.

Bezerra Jr. L., Junior X. G. D. \& Neumann-Leitão, S. 2011. Diversidade de larvas de peixes das áreas internas e externas do porto de Suape (Pernambuco - Brazil). Trop. Ocean. 39 (1): 1-13.

Boehlert, G. W., \& Morgan, J. B. 1985. Turbidity enhances feeding abilities of larval Pacific herring Clupea harengus pallasi. Hydrobiologia 123: 161-170.

Borja, A.; Dauer, D. M.; Elliott, M. \& Simenstad, C. A. 2010. Medium- and long-term recovery of estuarine and coastal ecosystems: Patterns, rates and restoration effectiveness. Estuar. Coast. 33: 1249-1260.

Brandini, F.P.; Lopes, R.M.; Gutseit, K.S.; Spach, H.L. \& Sassi, R. 1997. Planctonologia na Plataforma Continental do Brasil. Diagnose e Revisão Bibliográfica. REVIZEE. MMA, CIRM, FEMAR, Rio de Janeiro, 196p.

Campos, E. J. D., Gonçalves, J. E. \& Ikeda, Y. 1995. Water mass characteristics and geostrophic circulation in the South Brazil Bight - summer of 1991. J. Geophys. Res. 100: 18537-18550.

Cirano M \& Lessa G.C. 2007. Oceanographic characteristics of Baía de Todos os Santos, Brazil. Braz. J. Geophys. 25(4): 363-387.

Colby, D., \& D. Hoss. 2004. Larval fish feeding responses to variable suspended sediment and prey concentrations. DOER Technical Notes Collection (ERDC TN-DOER-E16 U.S. Army Engineer Research and Development Center, Vicksburg, MS.

Conselho Nacional de Meio Ambiente (CONAMA); Resolução no. 357 de 15 de março de 2005. Brasília, DF, 2005.

CRA - Centro de Recursos Ambientais. 2000. Saneamento ambiental da Baía de Todos os Santos. Technical Report RT-257-03-GR-002-RF, $248 \mathrm{pp}$.

Cundy, A. B., Croudace, I. W., Cearreta, A. \& Irabien, M. J. 2003. Reconstructing historical trends in metal input in heavily-disturbed, contaminated estuaries: studies from Bilbao, Southampton Water and Sicily. Appl. Geochem. 18: 311-325.

Engler, R.; Saunders, L. \& Wright, T. 1991. Environmental effects of aquatic disposal of dredged material. Environ. Prof. 13: 317-325.

Fahay, M. P., 1983. Guide to the early stages of marine fishes occurring in the western North Atlantic Ocean, Cape Hattaras to the southern Scotian Shelf. J. Northwest Atl. Fish. Sci. 4: 1-423.

Ferreira, A.N., Bereta, M. \& Mafalda Jr., P. 2012. Avaliação do impacto da dragagem sobre a associação fitoplanctônicas, do Porto de Aratu, 
Baía de Todos os Santos, Bahia. Arq. Ciên. Mar 45(1): $30-46$.

INMET - INSTITUTO NACIONAL DE METEOROLOGIA. Available in: www.inmet.gov. br. Acessed: 25/01/2012.

Jiang M., Wang Y., Lin Q. X., Shen, Z. \& Yuan, Q. X. 2008. Distribution characteristics of fish eggs and larvae around Yangshan Port in Hangzhou Bay [J];Mar. Environ. Sci. 2008: 01.

Katsuragawa, M.; Zani-Teixeira, M. L.; Goçalo, C. G.; Ohkawara, M. H. \& Itagaki, M. K. 2011. Ichthyoplankton distribution and abundance in the northern Todos os Santos and Camamu Bays, Bahia State. Brazil. Braz. J. Oceanogr., 59 (1): 97-109.

Kennish, M. J., 1986. Ecology of estuaries: biological aspects. Boca Raton, CRC Press. 390p.

Kingsford, M. J. \& Gray, C. A. 1996. Influence of pollutants and oceanography on abundance and deformities of wild fish larvae. In: Schmit, R. J. \& Osenberg, C. W. (Eds.). Detecting ecological impacts : Concepts and applications in coastal habitats. San Diego: Academic Press. 235-255pp.

Koening, M.L.; Eskinazi-Leça, E.; Neumann-Leitão, S. \& Macêdo, S.J. 2002. Impactos da construção do Porto de Suape sobre a comunidade fitoplanctônica no estuário do rio Ipojuca (Pernambuco-Brasil). Acta Bot. Bras., 16(4): 407-420.

Leis, J.M. \& Remmis, D.S. 1983. The Larvae of IndoPacific Coral Reef Fishes. New South, Sydney, Wales University Press, 269p.

Lessa, G. C.; Cirano, M.; Genz, F.; Tanajura, C. A. S. \& Da Silva, R. R. 2009. Oceanografia física. In: Hatje, V.; Andrade, J. B. DE, ed. EDUFBA, Salvador-Bahia. 67-119pp.

Lessa G. G., Dominguez J. M. L., Bittencourt A. C. S. P. \& Brichta A. 2001 The tides and tidal circulation of Todos os Santos Bay, Northeast Brazil: a general characterization. Anais da Academia Brasileira de Ciências 73: 245-261.

Lewis, M.A., Weber, D.E., Stanley, R.S. \& Moore, J.C. 2001. Dredging impact on an urbanized Florida bayou: effects on benthos and algal-periphyton. Environmental Pollution 115: 161-171

Li G. G., Wu Z. Y. \& Yu Z. M. 2007. Effects of drawing water and dredging on Rotifera community in the West Lake, Hangzhou. Acta Hydrobiol. Sin. 31(3): 386-392.

Lutz, H. C., Clarke, D. G. \& Suedel, B. C., 2012. A Fish Larvae and Egg Exposure System (FLEES) for Evaluating the Effects of Suspended Sediments on Aquatic Life. DOER Technical Notes Collection (ERDC TN-DOER-E16 U.S. Army Engineer Research and Development Center, Vicksburg, MS.
Mafalda Jr, P.O.; Souza, P.M DE; DA Silva, E.M. 2003. Estrutura hidroquímica e biomassa planctônica no Norte da Baía de Todos os Santos, Bahia, Brasil. Trop. Ocean. 31(1): 31-51.

Mafalda Jr., P.; Sinque, C.; Brito, R. R. C. \& Santos, J. J. 2004. Biomassa planctônica, hidrografia e pluviosidade na costa norte da Bahia, Brasil. Trop. Ocean. 32(2):145-160.

Mafalda Jr, P., Sinque, C. \& Muelbert, H. 2006. Associações de Larvas de Peixes na Costa Norte da Bahia. Atlântica 28(19): 5-11.

Mafalda Jr, P., O.; Souza, C. S. \& Velame, M. P. B. 2008. Fish larvae assemblage of a coastal area under influence of petrochemical activities, in Todos os Santos Bay, Bahia, Brazil. Aquat. ecosyst. health manag. 11: 457-464.

Margalef, R. 1983. Limnologia. 1009p. Barcelona: OMEGA.

Morgan, R. P. II, V. J. Rasin, JR. \& Noe, L. A. 1983. Sediment effects on eggs and larvae of striped bass and white perch. T. Am. Fish. Soc. 112:220-224.

Mouny, P. \& Dauvin, J.C. 2002. Environmental control of mesozooplankton community structure in Seine estuary (English Channel). Oceanol. Acta 25: 13-22.

Nayar, S., Goh, B.P.L. \& Chou, L.M. 2004. Environmental impact of heavy metals from dredged and resuspended sediments on phytoplankton and bacteria assessed in in situ mesocosms. Ecotox. Environ.I Safe. 59: 349-369.

Nelson J.S. 1994. Fish of the world. 3rd edition. New York: John Wiley \& Sons.

Neumann, V.H.; Medeiros, C.; Parente, L.; NeumannLeitão, S. \& Koening, M. L. 1998. Hydrodynamism, sedimentology, geomorphology and plankton changes at Suape area (Pernambuco - Brazil) after a port complex implantation. An. Acad. Bras. Cienc. 70(2): 313-323.

Newell, R.C., Seiderer, L.J. \& Hitchcock, D.R. 1998. The impact of dredging works in coastal waters: a review of the sensitivity to disturbance and subsequent recovery of biological resources on the sea bed. Ocean. Mar. Biol.: An Annual Review 36: 127-178.

Nogueira, M G. \& Matsumura - Tundisi, T. 1996. Limnologia de um ecossistema artificial raso (Represa do Monjolinho - São Carlos, SP) Dinâmica das populações planctônicas. Acta Limnol. Bras. 8: 149 - 168.

Otero, M.E.B.; Spach, H.L.; Pichler, H.A.; Queiroz, G.M.L.N.; Santos, C. \& Silva, A.L.C. 2006. O uso de atributos das assembléias de peixes para avaliar a integridade biótica em hábitats rasos das Baías de Antonina e Paranaguá, Paraná. Acta Biol. Par. 35(1-2): 69-82. 
Patchineelam S.M., Soares, C.R. \& Calliari, L.J. 2008. Assoreamento, aterros e dragagens. P.335-349 In: Baptista Neto, J.A., Wallner Kersanach, M. \& Patchineelam, S.M. (Orgs.). Poluição Marinha. Rio de Janeiro, Editora Interciência, 412p.

Pereira, M. G. \& Lessa, G. C. 2009. Varying patterns of water circulation in Canal de Cotegipe, Baía de Todos os Santos. Rev. Bras. Geof. 27.

Queiroz, G.M.L.N.; Spach, H.L.; Sobolewski-Morelos, M. \& Schwarz Jr., R. 2007. A ictiofauna demersal de áreas com diferentes níveis de ocupação humana, no estuário de Paranaguá. Arq. Cienc. Mar 40(2): 80-91.

Richards, W. J. 2006. Early stages of Atlantic fishes: an identification guide for the western central North Atlantic. CRC Press, 1824p.

Silva, A.P; Neumann-Leitão, S.; Schwamborn, R.; Gusmão, L.M; Almeida \& Silva, T. 2004. Mesozooplankton of an Impacted Bay in North Eastern Brazil. Braz. Arch. Biol. Techn. 47(3): 485-493.

SMEWW- Standard Methods for Examination of water and waster, $21^{\mathrm{a}} \mathrm{ed}, 2005$.

Strydom, N.A., Whitfield, A.K. \& Wooldridge, T.H. 2003. The role of estuarine type in characterising early stage fish assemblages in warm temperate estuaries, South Africa. African Zool. 38: 29-43.

Tackx, M. L. M., Nathalie, D. P., Riet, V. M., Azémar, F., Hannouti, A., Damme, S., Fiers, F., Daro, N. \& Meire, P. 2004. Zooplankton in the Schelde estuary, Belgium and the Nederlands. Spatial and temporal pattern. J. Plankton Res. 26: 133-141.

Taylor, S. E., Birch, G. F. \& Links, F. 2004. Historical catchment changes and temporal impact on sediment of the receiving basin, Port Jackson, New South Wales. Aust. J. Earth Sci. 51: 233-246.

Ter Braak, C. J. F. \& Smilauer, P. 1998. CANOCO Reference Manual User's Guide to Canoco for Windows. Microcomputer Power, Ithaca, USA. 352p.

Ter Braak, C.J.F. 1986. Canonical correspondence analysis: a new eigenvector technique for multivariate gradient analysis. Ecology, 67 (5): 1167-1179.
Vélez, J. A., Watson, W., Arntz, W., Wolff, M. \& SchnackSchiel, S. B. 2005. Larval fish assemblages in Independencia Bay, Pisco, Peru: temporal and spatial relationships. Mar. Biol. 147: 77-91.

Veado, L.D.V. \& C. Resgalla JR. 2005. Alteração da comunidade zooplanctônica do saco dos Limões após impacto das obras da via expressa sul - Baía Sul da Ilha de Santa Catarina. Braz. J. Aquat. Sci. Technol. 9(2): 65-73.

Wang, X.Y; Feng, J. \& Li, H. 2005. Research on variety of plankton community prior and post sediment dredging in Nanhu Lake, Changchun, J. Northeast Norm. Univ. 37(3): 90-94.

Whitfield A.K. \& Paterson A.W. 2003. Distribution patterns of fishes in a freshwater deprived Eastern Cape estuary, with particular emphasis on the geographical headwater region. Water SA (Pretoria) 29: 61-67.

Wilber, D. H. \& Clarke, D. G. 2001. Biological effects of suspended sediments: a review of suspended sediment impacts on fish and shellfish with relation to dredging activities in estuaries. N. Am. J. Fish. Manage. 21: 855-875.

Wolgemuth, K. M., Burnett, W. \& Moura P. L. 1981. Oceanography and suspended material in Todos osSantos Bay. Rev. Bras. Geoc. 11(3): 172-178.

Wu Z. Y., Yu Z. M., Sheng H. Y., Xu J., Han Y. C. \& $\mathrm{Xu}$ Y. T. 2008. Ecological efects of the dredging in the West Lake, Hangzhou. J. Lake Sci. 20(3): 277-284.

Yeager, K. M.; Brinkmeyer, R.; Rakocinski, C. F.; Schindler, K. J. \& Santschi, P. H. 2010.Impacts of dredging activities on the accumulation of dioxins in surface sediments of the Houston Ship Channel, Texas. J. coast. Res. 26: 743-752.

Zhang, S., Zhou, Q., Xu, D., Lin, J., Cheng, S. \& Wu, Z. 2010. Effects of sediment dredging on water quality and zooplankton community structure in a shallow of eutrophic lake. J. Environ. Sci. 22(2): 218-224.

Submetido: Janeiro/2013 Revisado: Março/2014 Aceito: Março/2014 